\title{
Isolation and Identification of Streptomyces spp. from Desert and Savanna Soils in Sudan
}

\author{
Mohamed E. Hamid 1,2,*(D), Adil Mahgoub 2,3, Abdulrhman J. O. Babiker 4 , \\ Hussein A. E. Babiker ${ }^{5}$, Mohammed A. I. Holie ${ }^{3}$, Mogahid M. Elhassan ${ }^{6}$ and \\ Martin R. P. Joseph ${ }^{1}$ \\ 1 Department of Clinical Microbiology and Parasitology, College of Medicine, King Khalid University, \\ P.O. Box 641, Abha 61314, Saudi Arabia; amarmartin4u@gmail.com \\ 2 Department of Preventive Medicine, Faculty of Veterinary Medicine, University of Khartoum, \\ Khartoum North 13314, Sudan; adilmahgo333@gmail.com \\ 3 Department of Microbiology, College of Medical Laboratory Science, Alzeim Alazhari University, \\ Khartoum North 12217, Sudan; microedu713@gmail.com \\ 4 Al-Amal National Hospital, Khartoum North 23622, Sudan; abdohu1995@gmail.com \\ 5 Department of Clinical Science, College of Veterinary Medicine, King Faisal University, P.O. Box 400, \\ Al-Ahsa 31982, Saudi Arabia; hbabiker@kfu.edu.sa \\ 6 Department of Clinical Laboratory Science, College of Applied Medical Science, Taibah University, \\ Al-Madinah 13215, Saudi Arabia; mmemam@taibahu.edu.sa \\ * Correspondence: mehamid3@gmail.com; Tel.: +966-5-0977-3687
}

Received: 20 September 2020; Accepted: 12 November 2020; Published: 25 November 2020

\begin{abstract}
The purpose of this study was to investigate streptomycete populations in desert and savanna ecozones in Sudan and to identify species based on 16S rRNA gene sequences. A total of 49 different Streptomyces phenotypes (22 from sites representing the desert and semi-desert ecozone; 27 representing the savanna ecozone) have been included in the study. The isolates were characterized phenotypically and confirmed using 16S rRNA gene sequence analysis. The two ecozones showed both similarities and uniqueness in the types of isolates. The shared species were in cluster 1 (Streptomyces (S.) werraensis), cluster 2 (Streptomyces sp.), cluster 3 (S. griseomycini-like), and cluster 7 (S. rochei). The desert ecozone revealed unique species in cluster 9 (Streptomyces sp.) and cluster 10 (S. griseomycini). Whereas, the savanna ecozone revealed unique species in cluster 4 (Streptomyces sp.), cluster 5 (S. albogriseolus/ S. griseoincarnatus), cluster 6 (S. djakartensis), and cluster 8 (Streptomyces sp.). Streptomycetes are widely distributed in both desert and the savanna ecozones and many of these require full descriptions. Extending knowledge on Streptomyces communities and their dynamics in different ecological zones and their potential antibiotic production is needed.
\end{abstract}

Keywords: actinomycetes; ecosystem; biodiversity; phenotypic identification; 16S rRNA gene

\section{Introduction}

The phylum Actinobacteria (order Actinomycetales) hosts diverse high G+C, Gram-positive bacteria including members of the genus Streptomyces (S.) Streptomycetes are Gram-positive spore-forming bacteria which include more than 900 species (https://www.ncbi.nlm.nih.gov/Taxonomy/ Browser/wwwtax.cgi?id=1883). Streptomyces represents the largest taxonomic group within the Bacteria Domain which is ubiquitously distributed in both aquatic and terrestrial ecosystems [1,2]. They are found in a wide range of habitats but are particularly abundant in soil, representing around 1 to $20 \%$ of the total viable count [2,3] and are known to prefer the characteristic earthy smell (geosmin) [4]. Streptomycetes are chemoheteroorganotrophs and are distinguished by their tough, leathery colonies and filamentous growth. They have an important ecological role in the turnover of organic material and 
are capable of using complex organic materials such as carbon and energy sources in the breakdown of these products in the soil [5].

The microbial communities including streptomycetes are affected by biotic and abiotic factors, notably vegetation, type of soil, and climate [6] Actinomycetes' diversity, and particularly that of streptomycetes, is widely documented for various reasons including the continued generation of environmental isolates for pharmaceutical, biodegradative, and biotechnological screening. Actinomycetes isolated from soil and related substrates show primary biodegradative activity [5].

Exploring new habitats around the globe is increasingly becoming the focus for discovering new taxa of Actinobacteria, namely streptomycetes, for potential antibacterial, antitumoral, and antifungal activities $[7,8]$. The habitat of Sudan has remained virtually untouched except for very few studies. Some areas in Sudan were found to be rich sources of microbial biodiversity, holding within them immense novelty and potentiality of identifying new isolates for the production of life-saving drugs such as amphotericin A. Marine habitats of Sudan were found to be a promising source for Streptomyces spp. diversity and a potential source of production of secondary metabolites [9]. Two actinomycin D-producing streptomycetes from Sudanese soil have been characterized and were found to be different from previous actinomycin-producing species [10]. The finding of distinct phylogenetic lineages and the variation in the spatial distribution of clones suggests that selection pressures may vary over the soil landscape [11].

This study aimed to isolate and identify streptomycetes from desert and savanna ecozones in Sudan and to find out the species diversity in the two ecozones using 16S rRNA gene analysis.

\section{Materials and Methods}

\subsection{Study Samples and Geographical Locations}

Soil samples were collected from different sites in two ecozones: (1) a desert and semi-desert ecozone, and (2) a low rainfall woodland savanna ecozone (Figure 1), according to the ecological classification by Harrison and Jackson [12]. The soil samples were collected during the dry season from the surface as well as from 5-10 cm deep. From five sections, $10 \mathrm{~g}$ within each site were collected with a sterilized spatula. Soils were then merged, sieved, and thoroughly mixed. The composite sample was transferred into sterile plastic bags, labeled, transported to the laboratory, and stored at $4{ }^{\circ} \mathrm{C}$ awaiting analysis.

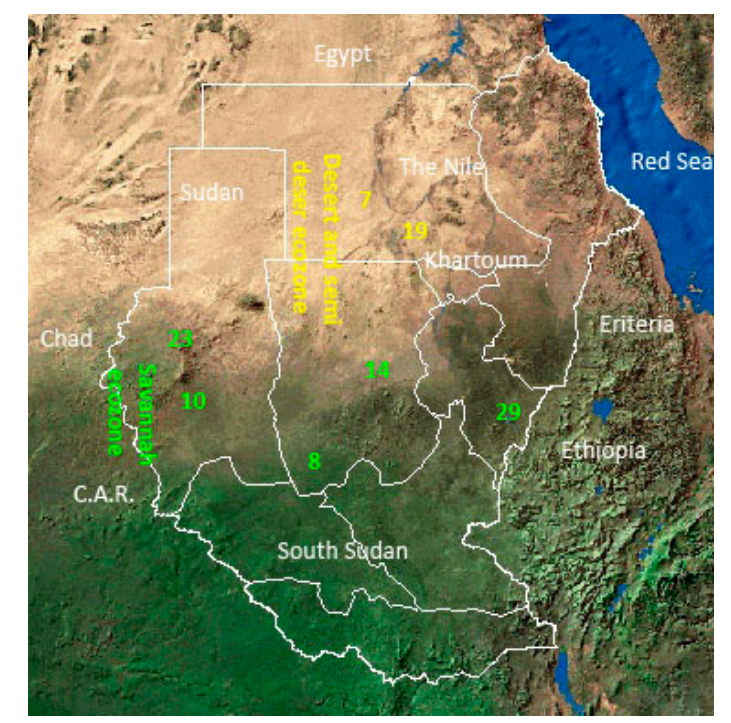

Figure 1. Map of Sudan showing soil collection sites and ecological zones (modified from the World Conservation Union (IUCN) (http://www.catsg.org/cheetah/04_country-information/North-Africanregions/sudan/sudan-sat2.jpg). 


\subsection{Pretreatment of Soil Samples}

The Higher Nitrogen Content (HNC) medium [13] was used as a pretreatment method to assist the extraction and isolation of streptomycetes from soil. $\mathrm{HNC}$ medium was prepared and stored at $4{ }^{\circ} \mathrm{C}$. After collection, $0.5 \mathrm{~g}$ of each soil sample was added to $50 \mathrm{~mL}$ HNC medium in a sterile Erlenmeyer flask. Flasks were placed on a shaker at $42{ }^{\circ} \mathrm{C}$ for $1 \mathrm{~h}$. The suspension was left for $5 \mathrm{~min}$ and transferred to a clean Falcon tube.

\subsection{Isolation of Streptomyces spp.}

The International Streptomyces Project agar number 2 (ISP2) [14] supplemented with cycloheximide $(50 \mu \mathrm{g} / \mathrm{mL})$, nystatin $(40 \mu \mathrm{g} / \mathrm{mL})$ and nalidixic acid $(54.9 \mu \mathrm{g} / \mathrm{mL})$ and $1 \mathrm{~mL}$ vitamin solution (filtered stock solution in $80 \mathrm{~mL}$ DW. pH 7: folate, $1 \mathrm{mg}$ [ $(0.0125 \mu \mathrm{g} / \mathrm{mL})$; biotin, $1 \mathrm{mg}(0.0125 \mu \mathrm{g} / \mathrm{mL})$; p-aminobenzoic acid, $20 \mathrm{mg}(0.25 \mu \mathrm{g} / \mathrm{mL})$; thiamine, $\mathrm{HCl}, 100 \mathrm{mg}(1.25 \mu \mathrm{g} / \mathrm{mL})$; pantothenic acid, $120 \mathrm{mg}(1.5 \mu \mathrm{g} / \mathrm{mL})$; riboflavin, $100 \mathrm{mg}(1.25 \mu \mathrm{g} / \mathrm{mL})$; nicotinic acid, $230 \mathrm{mg}(2.875 \mu \mathrm{g} / \mathrm{mL})$; vitamin B12, $10 \mathrm{mg}((0.125 \mu \mathrm{g} / \mathrm{mL})]$ was used for the isolation and cultivation of Streptomyces spp. Subsequent to autoclaving and cooling to $40^{\circ} \mathrm{C}$, the medium was supplemented with cycloheximide $(50 \mu \mathrm{g} / \mathrm{mL})$, nystatin $(40 \mu \mathrm{g} / \mathrm{mL})$ and nalidixic acid $(54.9 \mu \mathrm{g} / \mathrm{mL})$ to inhibit bacterial and fungal contamination.

Samples were diluted as 1:0 (no dilution); 1:5; 1:10; and 1:30. From each dilution, $0.1 \mathrm{~mL}$ was evenly spread onto the ISP2 medium using a sterile Drigalski spatula. Inoculated plates were incubated at $28^{\circ} \mathrm{C}$ for up to three weeks. Suspected colonies were picked out and streaked onto fresh ISP2 medium to purify streptomycetes colonies [15]. The pure cultures were stored on sterile vials containing $20 \%$ glycerol solution at $-20^{\circ} \mathrm{C}$ for further analysis.

\subsection{Characterization of Soil Isolates}

The predictable Streptomyces isolates were studied for morphological and microscopic properties using light microscopy [2]. Strains that showed mutual characteristics were clustered to form preliminary Streptomyces color groups for further analysis.

\subsection{Molecular Identification of Soil Isolates}

The 16S rRNA gene amplification and determination of a reasonable size sequence were performed as described by Rainey et al. [16]. Amplification from the genomic DNA samples was done using the eubacterial universal primers 27 F 5' -AGAGTT TGA TCC TGG CTC AG-3' and 1492R 5' -GGT TAC CTT GTT ACG ACT T-3' [17]. Amplification reactions were performed in a final volume of $20 \mu \mathrm{L}$, containing Promega Green Mix. The thermal cycling conditions were as follows: initial denaturation at $94{ }^{\circ} \mathrm{C}$ for $5 \mathrm{~min} ; 31 \mathrm{cycles}$ at $95^{\circ} \mathrm{C}$ for $30 \mathrm{~s}, 54^{\circ} \mathrm{C}$ for $90 \mathrm{~s}$ and $72{ }^{\circ} \mathrm{C}$ for $120 \mathrm{~s}$; and a final extension at $72{ }^{\circ} \mathrm{C}$ for $5 \mathrm{~min}$. The amplification reaction was performed by Bio-Rad thermal cycler (MyCycler, Bio-Rad, California, CA 94404, USA) and the amplified products were examined by $1 \%$ agarose gel electrophoresis.

For 16S rRNA gene sequencing, the chromosomal DNA was isolated from a 7-day culture using the PEG 200 (polyethylene glycol, Sigma-Aldrich, Munich, Germany). PCR-mediated amplification of the 16S rRNA gene and DNA sequencing were carried out with two universal primers, 27F and 1492R [18]. The ABI 370XL 96-capillary DNA analyzer (Applied Biosystems) and SeqMan software (DNASTAR) were used to analyze and assemble the gene sequences.

Obtained DNA sequences were first examined and corrected using Chromas (version 2.6.6 (2018), Technelysium Pty Ltd., South Brisbane, Queensland, Australia). These were then aligned with all available 16S rRNA gene sequences of validly described species using the EZbioCloud 16S database (www.ezbiocloud.net) to reveal an approximate phylogenetic relationship. The phylogenetic tree was constructed by the MEGA X program [19], using the Neighbor-joining method with bootstrap values based on 100 replications. 


\section{Results}

\subsection{Characteristics of the Study Samples}

The soil type in the desert (sites 7 and 19) was a Yermosol type [20] with an average annual temperature of $29.7^{\circ} \mathrm{C}$ and an average annual rain of $70 \mathrm{~mm}$. Savanna (sites 8, 10, 14, 23, and 29) had the following soil types: Arenosols, which are stabilized sand dunes with silt or clay mainly found in in sites 8, 10, 14, and 23; whereas site 29 (Ad Damazin; $11.7855^{\circ} \mathrm{N} ; 34.3421^{\circ} \mathrm{E}$ ) had Vertisols soil type. Savanna sites had annual temperatures range from 26.0 to $28.5^{\circ} \mathrm{C}$ and annual rainfall ranged from $213 \mathrm{~mm}$ in Al Fashir (13.6198 $\mathrm{N} ; 25.3549^{\circ} \mathrm{E}$ ) to $713 \mathrm{~mm}$ in Ad Damazin (site 29) (Figure 1).

\subsection{Isolation and Identification of Streptomyces spp.}

Different putative Streptomyces phenotypes (22 from sites representing the desert and semi-desert ecozone; 27 representing the savanna ecozone) were recovered and characterized. Various bacterial colonies appeared on ISP2 agar after 3 days of aerobic incubation at $28^{\circ} \mathrm{C}$ (Figure 2). Separation and purification of colonies by using the pick spot technique on ISP2 agar master plates were used to purify and store colony mass for further analysis.
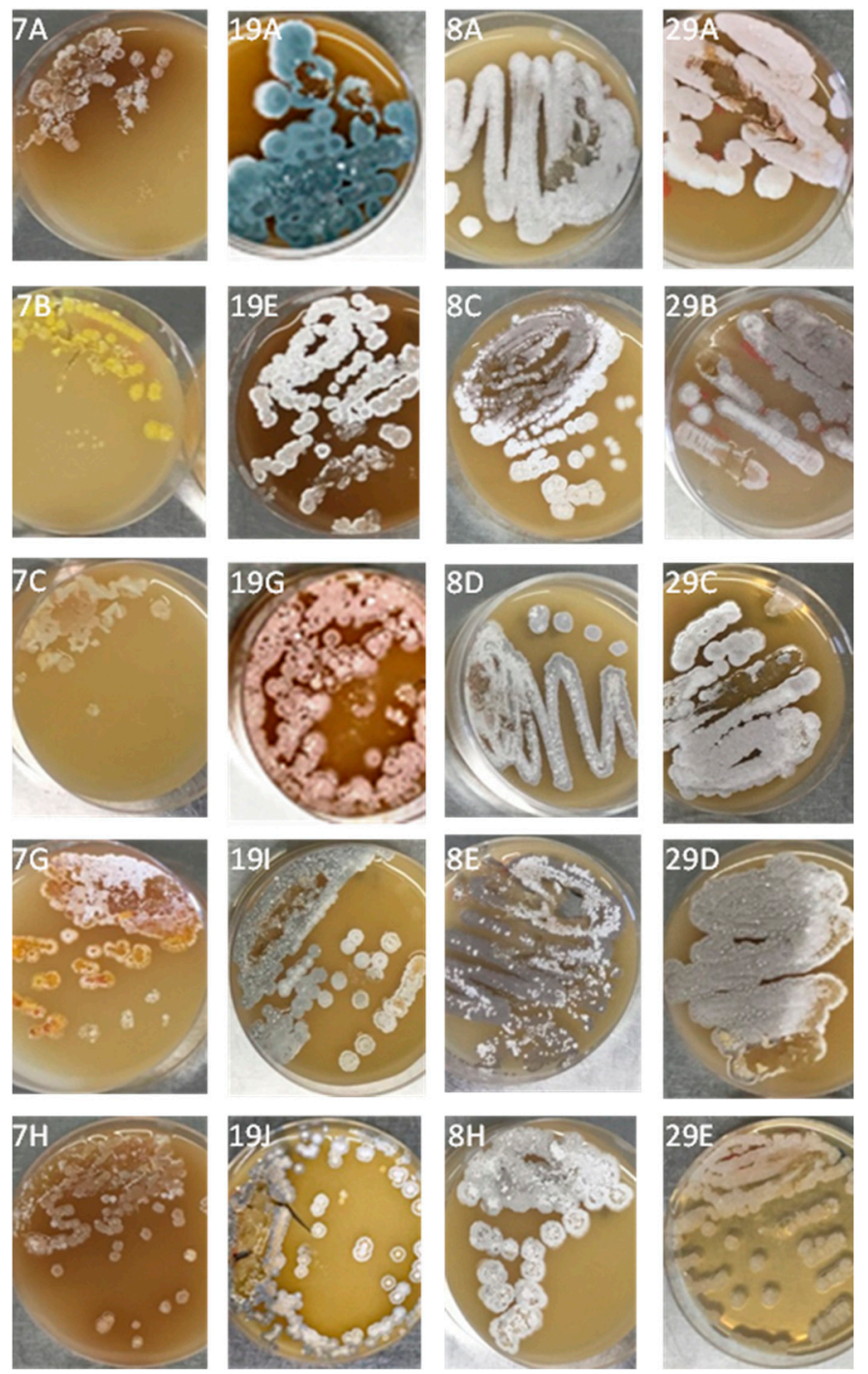

Figure 2. Colony morphology of Streptomyces spp. isolated from desert and savanna soils in Sudan using International Streptomyces Project agar number 2 (ISP2) media, incubated at $28^{\circ} \mathrm{C}$ for 15 days (plate's number indicates the soil site and letter indicates a phenotype). 


\subsection{Molecular Identification of Isolated Streptomycetes}

As a result of 16S rRNA gene sequencing, all 49 strains were confirmed as Streptomyces spp. based on partial 16S rRNA gene sequencing. Nucleotide sequence data have been deposited in GenBank and corresponding accession numbers are listed in Table 1. Isolate sequences were compared with sequences of Streptomyces type strains, and the relationships between the isolates and their closest phylogenetic neighbors are shown in Figure 3. Some sequences formed distinct phylogenetic lines, while others were grouped in clusters in the Streptomyces $16 \mathrm{~S}$ rRNA gene tree.

Table 1. Cluster analysis of streptomycete populations isolated from desert and savanna ecozones in Sudan and identified based on 16S rRNA gene analysis.

\begin{tabular}{|c|c|c|c|}
\hline Cluster/Species & Strain Code & Similarity Rate & GenBank Accession Number \\
\hline \multirow{6}{*}{ Cluster 1: Streptomyces (S.) werraensis } & $29 \mathrm{D}$ & $99.76 \%$ with $S$. werraensis & MF353969 \\
\hline & 19I & $100 \%$ with S. werraensis & MF353955 \\
\hline & $29 B$ & $100 \%$ with S. werraensis & MF353967 \\
\hline & $10 \mathrm{C}$ & $100 \%$ with S. werraensis & MF353939 \\
\hline & $8 \mathrm{E}$ & $100 \%$ with S. werraensis & MF353990 \\
\hline & $19 \mathrm{~J}$ & $99.77 \%$ with $S$. werraensis & MF356334 \\
\hline \multirow{4}{*}{ Cluster 2: Streptomyces sp. } & $7 \mathrm{O}$ & 99.76 with $S$. werraensis & MF356359 \\
\hline & 19D & $99.78 \%$ with $S$. werraensis & MF356332 \\
\hline & $7 \mathrm{E}$ & $99.19 \%$ with S. althioticus & MF356353 \\
\hline & $7 \mathrm{I}$ & $99.69 \%$ with S. althioticus & MF356355 \\
\hline \multirow{5}{*}{ Cluster 3: Streptomyces sp. } & $19 \mathrm{E}$ & $99.30 \%$ with S. werraensis & MF356333 \\
\hline & $14 \mathrm{H}$ & $99.32 \%$ with S. griseomycini & MF356328 \\
\hline & $19 \mathrm{~B}$ & $99.41 \%$ with $S$. griseomycini & MF353953 \\
\hline & $7 \mathrm{~A}$ & $98.11 \%$ with S. griseomycini & MF356350 \\
\hline & $7 G$ & $99.32 \%$ with S. griseomycini & MF356354 \\
\hline \multirow{3}{*}{ Cluster 4: Streptomyces sp. } & $8 \mathrm{~F}$ & $99.34 \%$ with S. albogriseolus & MF356361 \\
\hline & $8 \mathrm{H}$ & 99.77\% with S. albogriseolus. & MF353991 \\
\hline & $8 \mathrm{~A}$ & $99.36 \%$ with S. longispororuber & MF353987 \\
\hline \multirow{3}{*}{$\begin{array}{l}\text { Cluster 5: S. albogriseolus/S. } \\
\quad \text { griseoincarnatus }\end{array}$} & $8 \mathrm{~B}$ & $100 \%$ with S. albogriseolus & MF353988 \\
\hline & $8 \mathrm{D}$ & $100 \%$ with S. griseoincarnatus & MF353989 \\
\hline & $14 \mathrm{E}$ & $100 \%$ with $\stackrel{\circ}{S}$. djakartensis & MF353947 \\
\hline \multirow[t]{2}{*}{ Cluster 6: S. djakartensis } & $14 \mathrm{~J}$ & $100 \%$ with S. djakartensis & MF353948 \\
\hline & $14 \mathrm{~K}$ & $100 \%$ with S. djakartensis & MF353949 \\
\hline \multirow{4}{*}{ Cluster 7: S. rochei } & $7 \mathrm{~K}$ & $100 \%$ with S. rochei & MF353986 \\
\hline & $10 \mathrm{~B}$ & 99.70 with S. rochei & MF353938 \\
\hline & $7 \mathrm{~J}$ & $98.99 \%$ with S. rochei & MF356356 \\
\hline & $10 \mathrm{D}$ & $98.83 \%$ with S. rochei & MF353940 \\
\hline \multirow{2}{*}{ Cluster 8: Streptomyces sp. } & 14B & $99.42 \%$ with S. fragilis & MF356324 \\
\hline & $23 \mathrm{~B}$ & $99.79 \%$ with S. fragilis & MF353961 \\
\hline \multirow{2}{*}{ Cluster 9: Streptomyces sp. } & $7 \mathrm{C}$ & $97.69 \%$ with S. chromofuscus & MF356351 \\
\hline & $7 \mathrm{~N}$ & $99.29 \%$ with S. chromofuscus & MF356358 \\
\hline \multirow{2}{*}{ Cluster 10: S. griseomycini } & $19 \mathrm{H}$ & $100 \%$ with S. griseomycini & MF353954 \\
\hline & $7 \mathrm{~B}$ & $100 \%$ with S. griseomycini & MF353983 \\
\hline \multirow{4}{*}{ Cluster 11: Streptomyces sp. } & $14 \mathrm{D}$ & $98.88 \%$ with S. leeuwenhoekii. & MF356326 \\
\hline & $14 \mathrm{I}$ & $98.20 \%$ with S. carpinensis & MF356329 \\
\hline & $14 \mathrm{C}$ & $98.72 \%$ with S. leeuwenhoekii & MF356325 \\
\hline & $8 \mathrm{~L}$ & $98.65 \%$ with S. misionensis & MF356363 \\
\hline \multicolumn{4}{|l|}{ Single-membered clusters } \\
\hline Streptomyces sp. & 7D & $99.52 \%$ with S. levis & MF356352 \\
\hline Streptomyces sp. & $8 \mathrm{~N}$ & $99.62 \%$ with S. lomondensis & MF356364 \\
\hline Streptomyces sp. & $14 \mathrm{G}$ & $98.51 \%$ with S. hawaiiensis & MF356327 \\
\hline Streptomyces sp. & $19 \mathrm{~K}$ & $99.09 \%$ with S. fimbriatus & MF356335 \\
\hline Streptomyces sp. & $7 \mathrm{M}$ & $96.16 \%$ with S. griseoviridis & MF356357 \\
\hline Streptomyces sp. & $8 \mathrm{R}$ & $98.45 \%$ with $S$. deserti & MF356365 \\
\hline S. prasinosporus & $7 F$ & $100 \%$ with S. prasinosporus & MF353984 \\
\hline Streptomyces sp. & $19 \mathrm{~A}$ & $98.95 \%$ with S. malachitofuscus & MF356331 \\
\hline Streptomyces sp. & $7 \mathrm{H}$ & $99.88 \%$ with S. leeuwenhoekii. & MF353985 \\
\hline Streptomyces sp. & $8 \mathrm{C}$ & $98.93 \%$ with S. capitiformicae & MF356360 \\
\hline Streptomyces sp. & $8 \mathrm{G}$ & $99.61 \%$ with S. Ipomoeae & MF356362 \\
\hline Streptomyces sp. & $29 \mathrm{C}$ & $98.77 \%$ with $S$. matensis & MF353968 \\
\hline
\end{tabular}




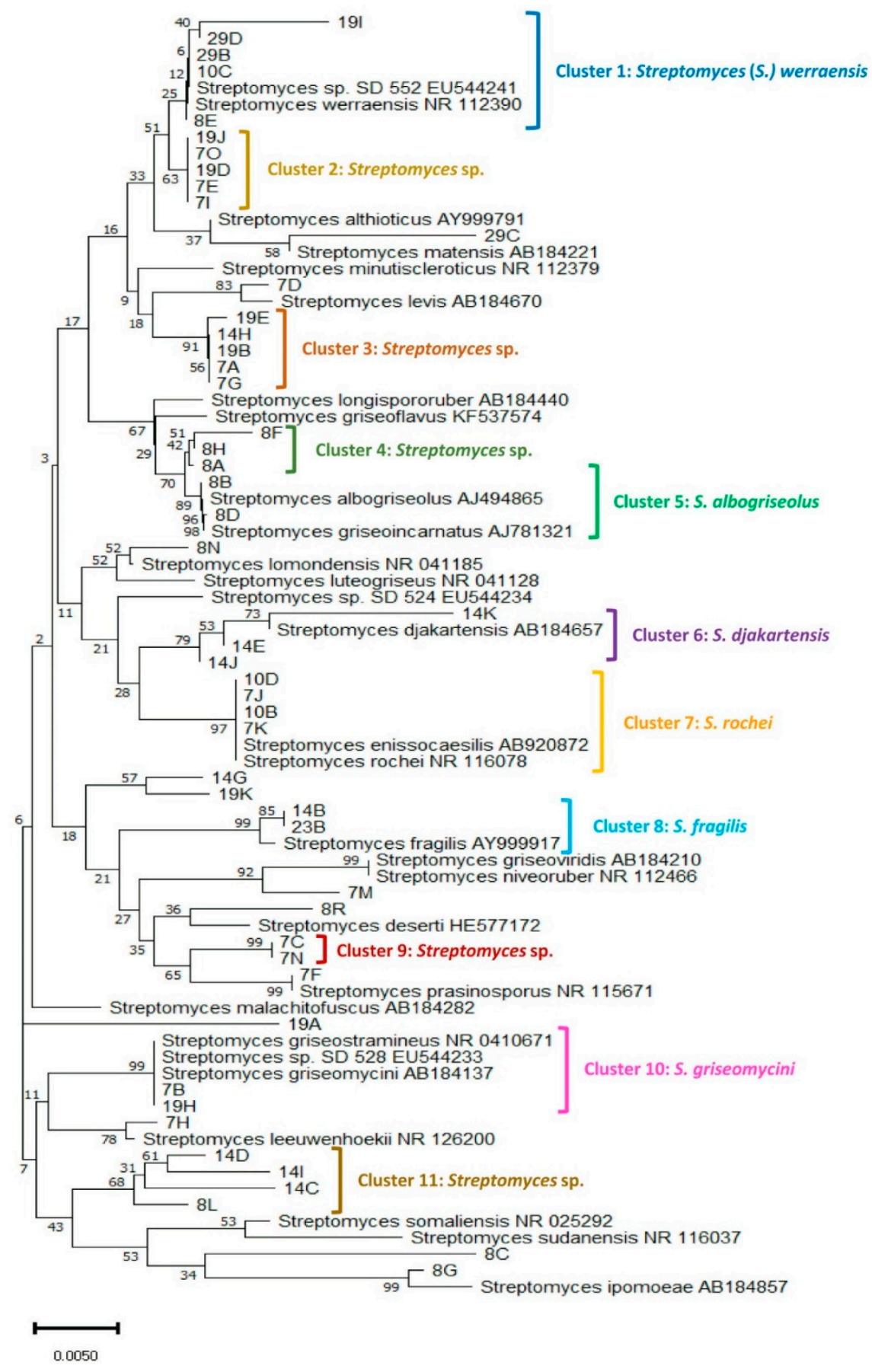

Figure 3. Phylogenetic relationships based on $16 \mathrm{~S}$ rRNA sequences amongst 49 Streptomyces strains in relation to closely related validly described species. Evolutionary analysis was based on the Neighbor-joining method using MEGA X software [19]. The bar represents 0.005 nucleotide substitutions per alignment position; numbers above the branches are bootstrap values.

The investigated ecozones displayed both resemblances and uniqueness in the types of isolates according to clusters and single-membered strains shown in Table 1 and Figure 3 . The shared species were in cluster 1 (S. werraensis), cluster 2 (Streptomyces sp.), cluster 3 (S. griseomycini-like), and cluster 7 (S. rochei). The desert ecozone revealed unique species in cluster 9 (Streptomyces sp.) and cluster 10 (S. griseomycini). Whereas the savanna ecozone revealed unique species in cluster 4 (Streptomyces sp.), cluster 5 (S. albogriseolus/ S. griseoincarnatus), cluster 6 (S. djakartensis), and cluster 8 (Streptomyces sp.) 


\section{Discussion}

Streptomycetes are widely distributed in nature, especially in soils with different structures and chemistry. This study was undertaken to highlight the presence of streptomycetes in two ecozones (ecosystems) and identify isolates to species levels. The results indicated the similarity in some types of the isolates as well as the uniqueness of each ecosystem. These findings emphasize the value for more analysis towards obtaining novel antimicrobial agents from these streptomycetes from either desert or savanna ecozones. Little scientific work has been carried out in this field, notably in the distinctive ecological ecozone of Sudan.

Many sub-Saharan African countries, including Sudan, have considerably diverse soils, such as clay in the east-central area and dunes in the west and north, all with variable climatic conditions [21]. A range of isolates from these soil types with different annual rainfall were noticed in this study (Figure 3, Table 1). Streptomyces species in cluster 9 (Streptomyces sp.) and cluster 10 (S. griseomycini). were isolated from the desert but not from the savanna. Likewise, the savanna ecozone, supposedly richer soil for agriculture, disclosed distinctive species namely in cluster 4 (Streptomyces sp.), cluster 5 (S. albogriseolus/ S. griseoincarnatus), cluster 6 (S. djakartensis), and cluster 8 (Streptomyces sp.). Many other single-member clusters have been found in both ecozones, many of them not fully identified as potential novel species giving their significant nucleotide dissimilarity with all known Streptomyces spp. Similar results were obtained from desert and semi-desert soils in Israel, where the differences observed were related to specific environmental factors rather than geographic distances and spatial distribution patterns [22].

It has been shown that numerical taxonomy is of established value both for the circumscription and identification of Streptomyces species [23,24]. This method was based on identifying various phenotypic characteristics of organism and the resultant data was analyzed by conventional statistics. It is true, however, that analyzing many phenotypic characteristics is neither easy to perform nor accurate in establishing identification to species level because biological similarities between species in a genus of over 700 members are high [2]. The application of the polyphasic taxonomical approach has been applied and successful, especially with actinomycetes. Even so, it is a labor- and time-intensive approach applying a plethora of techniques including traditional morphological and biochemical tests, DNA-DNA hybridization, and variation in 16S rRNA gene sequence [25]. Our approach in the present study was to study selected cultural and morphological characteristics and to confirm this initial identification with the sequencing analysis of the 16S rRNA gene. This attempt has been successful and saved a lot of time and money. However, not all isolates yielded the complete sequences or had poor endings and beginnings. Therefore, it remains one of the deficiencies of this study that the clustering and the phylogenetic tree was established based on partial gene sequencing for most of the isolates. Although dendrograms generated using both partial (ca. $500 \mathrm{bp}$ ) and complete (1500 bp) lengths, results were found to be basically the same with either length [26].

Different clades of Streptomyces spp. were found and different strains were isolated, showing a widespread range of antibacterials and differing modes of action [27]. The decrease in the average soil relative humidity and the increase in temperature explain significant reductions in the diversity and connectivity of these desert soil microbial communities and lead to significant reductions in the abundance of key taxa typically associated with fertile soils [28]. Such associations between the abundance of species and soil relative humidity of temperature has not been investigated in the present study and should be taken into consideration in future research. Streptomyces species are not just free-living soil organisms; they have a valuable ecological function in the soil as they have evolved to exist in symbiosis with plants, fungi, and animals [29]. Streptomycetes are recognized to yield many secondary metabolites that can reduce the growth of pathogens, including plant pathogens [30,31] and human pathogens [32-34]. It is probable that these antibiotics evolved as a direct result of their interactions with other organisms namely in symbiosis with fungi, plants, and animals [29,35]. Such interactions can be parasitic in the same way as the scab-causing streptomycetes [36] and those which infect humans $[37,38]$. The results of our present study can be a platform for exploiting this 
newly emerging field of research in which streptomycetes play influential roles in bio-control measures from these unusual and undiscovered fields and geographical locations.

The limitations of the present study include the fact that the dendrogram and the similarity matrices were established using partial lengths of the 16S rRNA gene in most of the strains. The use of almost complete sequences or the application of Multi-Locus Sequence Typing (MLST) will be needed for better descriptions of the unknown species. Microbial ecology and ecological characterization or metabolic characterization of isolated Streptomyces has not been conducted. Besides, screening for antimicrobial activities of the novel clusters from this investigation has not been done as well.

\section{Conclusions}

The present study has effectively isolated and identified several streptomycetes from two different ecozones. A notable percentage of these isolates fit in uncommon species and some may represent new species although the phylogenetic tree was created from partial 16S rRNA gene. We believe the information provided will be of use to the Streptomyces researchers.

Expanding relevant information on Streptomyces communities is still needed, especially studying their dynamic range in unique ecological ecozones and their ability to produce various antibiotics to combat increasing resistance to the known agents.

Author Contributions: Conceptualization, M.E.H. and M.M.E.; methodology, A.M. formal analysis, M.R.P.J., A.M., A.J.O.B., and H.A.E.B.; writing-original draft preparation, M.E.H.; writing—review and editing, H.A.E.B., M.M.E. and A.M.; project administration, M.A.I.H. All authors have read and agreed to the published version of the manuscript.

Funding: This work was supported by a fellowship from Alexander von Humboldt Foundation, Bonn, Germany (MEH; 3.4-SUD/1009961 STP) and the Deanship for Scientific Research, King Khalid University (Project \#GRP-28-1442).

Acknowledgments: The authors wish to thank the staff at the UFZ, Halle, especially Mika Tarkka, Thomas Reitz, Kerstin Hommel, and François Buscot for their considerable assistance, notably the hosting of the research and their help with the sequencing of the strains. We are grateful to Sawsan Abdelrahman, Abdelwahab Magzoub, Eng. Ahmed Sulieman Abdulaleem, Rabie Taha and Sheikh Hamaad for help with soil sample collection.

Conflicts of Interest: The authors declare no conflict of interest.

\section{References}

1. Barka, E.A.; Vatsa, P.; Sanchez, L.; Gaveau-Vaillant, N.; Jacquard, C.; Meier-Kolthoff, J.P.; Klenk, H.P.; Clement, C.; Ouhdouch, Y.; van Wezel, G.P. Taxonomy, physiology, and natural products of actinobacteria. Microbiol. Mol. Biol. Rev. 2016, 80, 1-43. [CrossRef] [PubMed]

2. Kämpfer, P. Family streptomycetaceae. In Bergey's Manual of Systematic Bacteriology. Volume 5: The Actinobacteria; Whitman, M.G.W., Kämpfer, P., Busse, H., Trujillo, M., Ludwig, W., Suzuki, K., Parte, A., Eds.; Springer: New York, NY, USA, 2012.

3. Kumar, R.R.; Jadeja, V.J. Isolation of actinomycetes: A complete approach. Int. J. Curr. Microbiol. Appl. Sci. 2016, 5, 606-618. [CrossRef]

4. Gerber, N.N.; Lechevalier, H.A. Geosmin, an earthly-smelling substance isolated from actinomycetes. Appl. Microbiol. 1965, 13, 935-938. [CrossRef] [PubMed]

5. McCarthy, A.J.; Williams, S.T. Actinomycetes as agents of biodegradation in the environment-A review. Gene 1992, 115, 189-192. [CrossRef]

6. Singh, S.K.; Rai, J.P. Soil microbial population and enzyme activity related to grazing pressure in alpine meadows of Nanda Devi Biosphere Reserve. J. Environ. Biol. 2004, 25, 103-107.

7. Das, R.; Romi, W.; Das, R.; Sharma, H.K.; Thakur, D. Antimicrobial potentiality of actinobacteria isolated from two microbiologically unexplored forest ecosystems of Northeast India. BMC Microbiol. 2018, $18,71$. [CrossRef]

8. Cumsille, A.; Undabarrena, A.; Gonzalez, V.; Claverias, F.; Rojas, C.; Camara, B. Biodiversity of actinobacteria from the South Pacific and the assessment of streptomyces chemical diversity with metabolic profiling. Mar. Drugs 2017, 15, 286. [CrossRef] 
9. Khattab, A.; Babiker, E.H.; Humodi, A.; Saeed, H.A. Streptomyces: Isolation, optimization of culture conditions and extraction of secondary metabolites. Int. Curr. Pharm. J. 2016, 5, 27-32. [CrossRef]

10. Hamza, A.A.; Ali, H.A.; Clark, B.R.; Murphy, C.D.; Elsheikh, A.; Elobaid, E.A. Isolation and characterisation of actinomycin D producing Streptomyces spp. from Sudanese soil. Afr. J. Biotechnol. 2013, 12, 2624-2632.

11. Davelos, A.L.; Xiao, K.; Samac, D.A.; Martin, A.P.; Kinkel, L.L. Spatial variation in Streptomyces genetic composition and diversity in a prairie soil. Microb. Ecol. 2004, 48, 601-612. [CrossRef]

12. Harrison, M.N.; Jackson, J.K. Ecological Classification of the Sudan; Forest Department, Forest Bulletin No. 2; Ministry of Agriculture: Sudan, North Africa, 1958.

13. Nonomura, H.; Hayakawa, M. New methods for the selective isolation of soil actinomycets. In Biology of Actinomycetes'88; Okami, Y., Ed.; Japan Scientific Societies Press: Tokyo, Japan, 1988; pp. 288-293.

14. Shirling, E.B.; Gottlieb, D. Methods for characterization of Streptomyces species. Int. J. Syst. Bacteriol. 1966, 16, 313-340. [CrossRef]

15. Williams, S.T.; Cross, T. Actinomycetes, Methods in Microbiology; Academic Press: New York, NY, USA, 1971; Volume 4.

16. Rainey, F.A.; Ward-Rainey, N.; Kroppenstedt, R.M.; Stackebrandt, E. The genus Nocardiopsis represents a phylogenetically coherent taxon and a distinct actinomycete lineage: Proposal of Nocardiopsaceae fam. nov. Int. J. Syst. Bacteriol. 1996, 46, 1088-1092. [CrossRef] [PubMed]

17. Lane, D.J.; Stackebrandt, E.; Goodfellow, M. 6S/23S rRNA sequencing. In Nucleic Acid Techniques in Bacterial Systematics; John Wiley \& Sons: New York, NY, USA, 1991.

18. Lane, D.J. 16S/23S rRNA sequencing. In Nucleic Acid Techniques in Bacterial Systematics; Stackebrandt, E., Goodfellow, M., Eds.; Wiley: Chichester, UK; New York, NY, USA, 1991; pp. 115-175.

19. Kumar, S.; Stecher, G.; Li, M.; Knyaz, C.; Tamura, K. MEGA X: Molecular evolutionary genetics analysis across computing platforms. Mol. Biol. Evol. 2018, 35, 1547-1549. [CrossRef] [PubMed]

20. Jones, A.; Breuning-Madsen, H.; Brossard, M.; Dampha, A.; Deckers Dewitte, O.; Gallali, T.; Hallet, S.; Jones, R.; Kilasara, M.; Le Roux, P.; et al. Soil Atlas of Africa; European Commission, Publications Office of the European Union: Luxembourg, 2013; ISBN 978-92-79-26715-4.

21. Burgess, N.D.; Hales, J.D.; Underwood, E.; Dinerstein, E. Terrestrial Ecoregions of Africa and Madagascar: A Conservation Assessment; Island Press: Washington, DC, USA, 2004.

22. Pasternak, Z.; Al-Ashhab, A.; Gatica, J.; Gafny, R.; Avraham, S.; Minz, D.; Gillor, O.; Jurkevitch, E. Spatial and temporal biogeography of soil microbial communities in arid and semiarid regions. PLoS ONE 2013, 8, e69705. [CrossRef] [PubMed]

23. Goodfellow, M.; Ferguson, E.V.; Sanglier, J.J. Numerical classification and identification of Streptomyces species-A review. Gene 1992, 115, 225-233. [CrossRef]

24. Konev Iu, E.; Mitnitskii, A.B. Numerical taxonomy of verticillate actinomycetes. Mikrobiologiia 1980, 49, 110-116.

25. Sangal, V.; Goodfellow, M.; Jones, A.L.; Schwalbe, E.C.; Blom, J.; Hoskisson, P.A.; Sutcliffe, I.C. Next-generation systematics: An innovative approach to resolve the structure of complex prokaryotic taxa. Sci. Rep. 2016, 6, 38392. [CrossRef]

26. Clarridge, J.E., 3rd. Impact of $16 \mathrm{~S}$ rRNA gene sequence analysis for identification of bacteria on clinical microbiology and infectious diseases. Clin. Microbiol. Rev. 2004, 17, 840-862. [CrossRef]

27. Bull, A.T.; Asenjo, J.A. Microbiology of hyper-arid environments: Recent insights from the Atacama Desert, Chile. Antonie Van Leeuwenhoek 2013, 103, 1173-1179. [CrossRef]

28. Neilson, J.W.; Califf, K.; Cardona, C.; Copeland, A.; van Treuren, W.; Josephson, K.L.; Knight, R.; Gilbert, J.A.; Quade, J.; Caporaso, J.G.; et al. Significant impacts of increasing aridity on the arid soil microbiome. mSystems 2017, 2. [CrossRef]

29. Seipke, R.F.; Kaltenpoth, M.; Hutchings, M.I. Streptomyces as symbionts: An emerging and widespread theme? Fems Microbiol. Rev. 2012, 36, 862-876. [CrossRef] [PubMed]

30. Newitt, J.T.; Prudence, S.M.M.; Hutchings, M.I.; Worsley, S.F. Biocontrol of cereal crop diseases using streptomycetes. Pathogens 2019, 8, 78. [CrossRef] [PubMed]

31. Rashad, F.M.; Fathy, H.M.; El-Zayat, A.S.; Elghonaimy, A.M. Isolation and characterization of multifunctional Streptomyces species with antimicrobial, nematicidal and phytohormone activities from marine environments in Egypt. Microbiol. Res. 2015, 175, 34-47. [CrossRef] [PubMed] 
32. Gajdacs, M. The concept of an ideal antibiotic: Implications for drug design. Molecules 2019, $24,892$. [CrossRef] [PubMed]

33. Hamid, M.E.; Reitz, T.; Joseph, M.R.P.; Hommel, K.; Mahgoub, A.; Elhassan, M.M.; Buscot, F.; Tarkka, M. Diversity and geographic distribution of soil streptomycetes with antagonistic potential against actinomycetoma-causing Streptomyces sudanensis in Sudan and South Sudan. BMC Microbiol. 2020, 20, 33. [CrossRef]

34. Bolourian, A.; Mojtahedi, Z. Streptomyces, shared microbiome member of soil and gut, as 'old friends' against colon cancer. Fems Microbiol. Ecol. 2018, 94. [CrossRef]

35. Kroiss, J.; Kaltenpoth, M.; Schneider, B.; Schwinger, M.G.; Hertweck, C.; Maddula, R.K.; Strohm, E.; Svatos, A. Symbiotic Streptomycetes provide antibiotic combination prophylaxis for wasp offspring. Nat. Chem. Biol. 2010, 6, 261-263. [CrossRef]

36. Bramwell, P.A.; Wiener, P.; Akkermans, A.D.; Wellington, E.M. Phenotypic, genotypic and pathogenic variation among streptomycetes implicated in common scab disease. Lett. Appl. Microbiol. 1998, 27, 255-260. [CrossRef]

37. Trujillo, M.E.; Goodfellow, M. Numerical phenetic classification of clinically significant aerobic sporoactinomycetes and related organisms. Antonie Van Leeuwenhoek 2003, 84, 39-68. [CrossRef]

38. Quintana, E.T.; Wierzbicka, K.; Mackiewicz, P.; Osman, A.; Fahal, A.H.; Hamid, M.E.; Zakrzewska-Czerwinska, J.; Maldonado, L.A.; Goodfellow, M. Streptomyces sudanensis sp. nov., a new pathogen isolated from patients with actinomycetoma. Antonie Van Leeuwenhoek 2008, 93, 305-313. [CrossRef]

Publisher's Note: MDPI stays neutral with regard to jurisdictional claims in published maps and institutional affiliations. 